Article

\title{
Fatty Acid Profile in Goat Milk from High- and Low-Input Conventional and Organic Systems
}

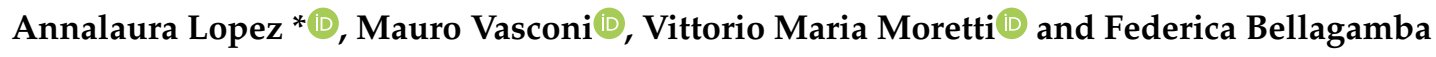 \\ Department of Health, Animal Science and Food Safety-Università degli Studi di Milano, Via Trentacoste 2, \\ 20134 Milano, Italy \\ * Correspondence: annalaura.lopez@unimi.it; Tel.: +39-0250315759; Fax: +39-0250315746
}

Received: 1 July 2019; Accepted: 15 July 2019; Published: 17 July 2019

check for updates

Simple Summary: The nutritional composition of goat milk is the focus of an ongoing discussion regarding its possible consideration as functional food. Different livestock production systems can lead to a different nutritional composition of milk. Some classes of fatty acids, detected in favourable amounts, are considered important bioactive components of food because of their potential beneficial effects on human health. It is an interesting topic to consider in view of the current debate regarding the incidence of dairy products in the risk of human coronary heart diseases. In our study, we confirmed that a low-input (LI) production system in goats rearing, leads to a milk richer in favourable nutritional components compared to a high-input (HI) system. Moreover, comparing lipid profile of milk obtained under different rearing systems, a multivariate statistic approach allows for the discrimination between LI-organically certified, LI-non organically certified and HI-conventional goat milk samples. These results may contribute to enhance the characterisation of goat dairy products and could help raise the appreciation of consumers towards goat dairy products, thereby adding value to their market.

\begin{abstract}
According to the knowledge that the composition in fatty acids of milk is related to the production system, we determined the fatty acid composition of goat milk yielded in three different Italian farms. Two low-input system farms; one organic (LI-O) and one conventional (LI-C), and one high-input system conventional farm (HI-C) were involved in the study. Significant differences were detected among the different groups considering the fatty acid pattern of milk. Fatty acids (FA) strictly related to the rearing system, such as odd and branched chain fatty acids (OBCFA), linoleic acid (LA, 18:2 n6), alpha-linolenic acid (ALA, 18:3 n3), elaidic acid (EA, 18:1 n9), total n6 and total n3 FA, were identified as the most significant factors in the characterization of samples coming from lowor high-input systems. OBCFA amounts were found to be higher $(p<0.05)$ in the LI-O milk $(4.7 \%)$, followed by the LI-C milk (4.5\%) and then by the HI-C milk (3.4\%). The same trend was observed for $\Sigma$ n 3 FAs, mainly represented by ALA $(0.72 \%-0.81 \%$ in LI-O systems and $0.41 \%$ in HI-system), and the opposite for $\Sigma \mathrm{n} 6 \mathrm{FAs}$, principally represented by LA $(2.0 \%-2.6 \%$ in LI-systems and $3.1 \%$ in HI-system). A significant $(p<0.01)$ discrimination among samples clusters coming from the different systems was allowed by the principal component analysis (PCA).
\end{abstract}

Keywords: goat milk; OBCFA; fatty acids; livestock production system; low-input; high-input

\section{Introduction}

The fatty acid (FA) composition and related factors variability in milk fat are recently renewed due to the impact of different FA classes in human nutrition, particularly, cis and trans monounsaturated fatty acids (MUFA), odd and branched chain fatty acids (OBCFA), conjugated linoleic acid (CLA) and polyunsaturated fatty acids (PUFA) [1,2]. Several studies aimed at discussing the linkage between 
animal diet and rumen microbiota, and the related effect on milk quality. The rumen bacteria population and mammary gland activity are the main responsible for biochemical mechanisms that include rumen biohydrogenation, mammary lipogenic and $\triangle 9$-desaturation in CLA and odd and branched chain formation [3-5]. Particularly the type of forage, forage to concentrate ratio (F/C), lipids supplementation and starch level, together with their interactions, significantly affect milk FA composition, including OBCFA. Bacterial OBCFA are major lipids of bacterial membranes [6,7]. A significantly different content of odd-chain (C15:0, C17:0, C17:1) fatty acids was reported in cow milk and cheese samples from a different pasture vegetation type, contributing in the characterization and protection of typical dairy products $[8,9]$. Branched chain fatty acids (BCFA), iso and anteiso forms relating to the methyl-group located on the penultimate carbon and on the antepenultimate carbon of the carbon chain, represent a lesser component of milk (about $2 \%-3 \%$ of total fatty acids). However, they are recognised as important bioactive components since their positive role in gastrointestinal microbial ecology and potential anti-cancer activity [10-13]. Cytotoxicity of these fatty acids might be compared to that of CLA to which much more attention has been spent, despite milk BCFA being more represented than milk CLA. Recently, the contribution of BCFA from various food, prominently featured in the American diet, has been estimated. These studies have shown that BCFA may have a beneficial effect on proper gut functions; thus, their intake becomes relevant for human health [11]. Grazing represents a right approach to improve healthful nutritional quality of milk lipid composition in ruminant species. Goat milk products seem to be enriched in OBCFA when compared to cow milk products [14], and this could be one of the criterions useful in enhancing the appreciation of consumers toward goat products, and to take them into account as possible functional foods. In goat milk, the OBCFA content was significantly affected by lipid supplementation and its interaction with forage levels $[15,16]$. Moreover, different percentages of diet concentrate affect the relative amount of $\mathrm{C} 13: 0$, iso-C15:0, and iso-C16:0 in goat fat milk [17]. Comparisons of organic and conventional farming system characterized by grazing and a reduced amount of conserved forage generally show a higher proportion of nutritionally favourable FA such as PUFA n3, rumenic acid and branched FA [18-22]. Diets rich in starch or a decrease in $\mathrm{F} / \mathrm{C}$ ratio and neutral detergent fibre (NDF) content promote the growth of amylolytic and go to detriment of cellulolytic bacteria with a consequent reduction of iso fatty acids in milk fat [5]. Generally, the conventional livestock production system adopted in dairy goat breeding in Italy, particularly in small mountain farms, is considered as semi-intensive. This could be the reason for the higher amount of OBCFA detected in goat products. It is interesting to determine if any difference or similarities exists among milk yielded in farms managed under different conditions. Particularly, in many goat farms, which we can consider as "low-input-system farms", the production system is not so different to that used in organic-certified farms, and this could lead to a similar nutritive and functional quality of yielded milk, even if it is not certified as organic [23]. Thus, the aim of this work was to evaluate the impact of different production systems in Italy on milk fatty acids composition of goat milk, with a particular focus on OBCFA.

\section{Materials and Methods}

\subsection{Animals, Housing and Feeding}

The experiment involved three goat farms from the end of March until October 2017. Each farm was considered for different peculiarities distinguishing its livestock production system. With high-input (HI), authors refer to the conventional, typically intensive, dairy goat rearing system in Italy, in which animals are always reared in the barn and the diet is mainly based on concentrates, conserved forage and a low F/C ratio all the year around. A conventional lowland farm with Saanen breed goats (HI-C) was selected to represent the HI production and feeding system (HI-C). In the HI-C farm, goats were fed by local ryegrass hay offered ad libitum, alfalfa hay offered once a day (about $500 \mathrm{~g} / \mathrm{d}$ ) during the first period of lactation and commercial feed, consisting of a mixture of flaked and flour cereals, distributed individually twice a day (totally $1200 \mathrm{~g} / \mathrm{d}$ ) during milking. Two farms were considered representing 
the low-input (LI) production system. In the LI-system, goats are mainly allowed to graze. In the barn, their diet is integrated with conserved forage and concentrates, with a higher $\mathrm{F} / \mathrm{C}$ ratio. A conventional mountain farm (altitude, $980 \mathrm{~m}$ ) with Alpine breed goats, represented the not-organically-certified LI breeding system in our study (LI-C). In the LI-C farm, goats grazed depending on favourable climatic conditions and other feed supplements were also included in the diet. In more detail, goats were fed $a d$ libitum with local polyphite grass hay (first harvest), alfalfa hay distributed once a day after the morning milking (about $500 \mathrm{~g}$ per goat per day) and concentrates (commercial mixtures) distributed twice a day during milking (totally 1000 g per goat per day). Finally, an organic Alpine breed goat farm (LI-O) was selected representing the organic-certified [24] system, in which, in addition to feeding, further organic-farming standard must be observed (LI-O). In this farm, lactating goats were systematically and daily grazed from spring to autumn (March-October); the access to fresh grass was controlled, starting after the morning milking and ending around noon (about 4 hours/day). Forage consisting of alfalfa hay (1000 g per goat per day) and polyphite grass hay (500 g) was distributed twice a day, firstly in the morning before grazing fresh pasture and after the second milking in the afternoon grains. A mixture of organically certified maize and barley grains (3:1, respectively), formulated in-farm, was supplied twice a day during milking (totally $800 \mathrm{~g} / \mathrm{d}$ ). In all three farms goats had free access to water and to salt integrators; no additional lipids were supplemented. Feeding (including access to pasture) and milk yield and composition data were recorded by information collected by farmers. The average daily feed intake per goat was evaluated on the basis of dry matter intake (DMI) prediction models for lactating goats reported by Pulina et al. [25], taking into account the goat's average size and milk yield for the lactation period involved in the study. Estimated intakes were calculated by fodder analysis of feedstuffs dry matter [26].

\subsection{Sampling}

All farms had similar proportions of goats in lactation at all sampling dates $(42,39$ and 45 in $\mathrm{HI}-\mathrm{C}$, LI-C and LI-O farms, respectively). Goats were machine milked twice a day in all farms. Bulk tank raw milk samples were sampled twice a month, from March ( $4 \pm 1$ week of lactation) to October, from two consecutive milking, corresponding to cheese making in farm. A total amount of 37 milk samples were stored at minus $20^{\circ} \mathrm{C}$ until the analysis of fatty acid composition. The measurement of fat, protein and lactose were assumed from monthly official controls, determined by near infrared spectrophotometry [27].

\subsection{Analytical Procedures}

To determine the fatty acids composition of milk, fat was extracted according to the method of Folch et al. [28]. Lipids were extracted from $10 \mathrm{~mL}$ of milk by chloroform methanol 2:1. Extracted milk fat was quantified and an aliquot (about $40-50 \mathrm{mg}$ ) was used for fatty acid composition analysis. Fatty acids were determined as methyl ester, prepared by base catalysed methanolysis of glycerides as described by Christie [29]. Lipids were dissolved in $1 \mathrm{ml}$ of diethyl ether, then $50 \mu \mathrm{L}$ of methyl acetate and $100 \mu \mathrm{L}$ of $1 \mathrm{M}$ sodium methoxide in methanol were added. The reaction was stopped after $5 \mathrm{~min}$ at room temperature by adding $50 \mu \mathrm{L}$ of an oxalic acid in diethyl ether saturate solution. After centrifugation at $1500 \mathrm{~g}$ for $5 \mathrm{~min}, 200 \mu \mathrm{L}$ of upper layer of solution was used directly for gas chromatography (GC) analysis. The injector was set in split mode (1:100 split ratio) at a constant temperature of $250^{\circ} \mathrm{C}$ and $1 \mu \mathrm{L}$ sample was injected. Fatty acid analysis was carried out on an Agilent gas-chromatograph (Model 6890 Series GC, Agilent Technologies, Santa Clara, CA, USA) fitted with an automatic sampler (Model 7683, Agilent Technologies, Santa Clara, CA, USA) and FID detector (Agilent Technologies, Santa Clara, CA, USA). The carrier gas was helium with a flow rate of $1.0 \mathrm{~mL}$ min- 1 and an inlet pressure of 16.9 psi. A TRACETM TR-FAME column $(60 \mathrm{~m}$ length, $0.25 \mathrm{~mm}$ i.d., $0.25 \mu \mathrm{m}$ film thickness; Thermo Fisher Scientific, Waltham, MA, USA) was used to separate fatty acid methyl esters. The oven temperature program for separation started with an isotherm of $6 \mathrm{~min}$ at $50{ }^{\circ} \mathrm{C}$, then the temperature increased at a rate of $10^{\circ} \mathrm{C} \mathrm{min}^{-1}$ until $170{ }^{\circ} \mathrm{C}$ and kept at this temperature 
for $30 \mathrm{~min}$. Afterwards the temperature was increased from $4{ }^{\circ} \mathrm{C} \mathrm{min}^{-1}$ to the final temperature of $220^{\circ} \mathrm{C}$ and hold for $20 \mathrm{~min}$.

Individual fatty acids methyl esters were identified by comparing sample peak retention times with standard mixtures (Supelco 37 FAME Mix, Supelco, Bellafonte PA, USA) and pure standard methyl esters from Sigma- Aldrich (Sigma-Aldrich, Saint Louis, MO, USA, cat n.CRM 47791) and expressed as percentage of total fatty acids. The identification of branched chain fatty acids was determined by preparing methyl esters from standards available (Sigma-Aldrich, Saint Louis, MO, USA), then analysed under the same instrumental condition. A gas-chromatographic correction factor has been applied to take into account the lower response of the flame ionization detector to the molecules with a lower number of carbon atoms for 4:0, 6:0, 8:0, 10:0 and 12:0 [30].

\subsection{Statistical Analyses}

The evaluation of different farming systems was calculated by the analysis of variance. Normal distribution (Shapiro-Wilk test) and homogeneity of variance (Levene test) were confirmed and comparison between means was performed by the ANOVA test when the normality and homoscedasticity assumptions were confirmed, and the Welch ANOVA F test when the assumptions were not confirmed. The Student Newman-Keuls was used as the post Hoc test for comparison of the means among different farming systems. Significance was declared at $p \leq 0.05$. Multivariate analysis (principal component analysis, PCA) was applied, taking into account all fatty acids of milk sampled as graphical projection technique, in order to study the distribution of samples in a two-dimensional space and to establish if any separation between different groups (LI-O, LI-C, HI-C) was feasible using measured variables. The statistical procedure was performed using JMP Pro 14 (SAS Institute Inc., Cary, NC, USA). Data in the tables are reported as mean values \pm standard deviation.

\subsection{Ethical Approval}

This article does not contain any experimental practice performed on animals by the authors. Only raw bulk milk sampling, considered a routine practice in farm, was performed in order to develop the present research. No biological material was collected. Authors guarantee that in the three farms involved in the study all the applicable guidelines for animal welfare established by harmonised EU rules were followed. No approval by the institutional ethics committee was requested by University of Milan for this kind of research.

\section{Results}

Table 1 discloses goat feed intake and milk proximate composition of farms involved in the study. Proximate composition did not show significant differences between the three groups, with the exception of protein concentration, which slightly increased in HI-C farm $(p<0.05)$.

Table 1. Feed intake and milk yield (per goat per day) and composition in LI-O, LI-C, HI-C. Milk composition data are presented as mean \pm standard deviation for each farm.

\begin{tabular}{|c|c|c|c|c|c|c|c|c|c|c|}
\hline \multirow{3}{*}{ Item } & \multicolumn{10}{|c|}{ Farm } \\
\hline & \multicolumn{4}{|c|}{$\begin{array}{c}\text { LI-O } \\
\text { Low Input, Organic }\end{array}$} & \multicolumn{3}{|c|}{$\begin{array}{c}\text { LI-C } \\
\text { Low Input, Conventional }\end{array}$} & \multicolumn{3}{|c|}{$\begin{array}{c}\text { HI-C } \\
\text { High Input, Conventional }\end{array}$} \\
\hline & $C^{1}$ & $\mathrm{AH}^{2}$ & PGH $^{3}$ & $\mathbf{P}^{4}$ & $C^{1}$ & $\mathrm{AH}^{2}$ & PGH $^{3}$ & $\mathrm{C}^{1}$ & $\mathrm{AH}^{2}$ & $\mathrm{RH}^{5}$ \\
\hline supplied (g/day) & 800 & 1000 & 500 & Ad libitum & 1000 & 500 & Ad libitum & 1200 & 500 & Ad libitum \\
\hline $\mathrm{g} / \mathrm{Kg} \mathrm{DM}$ & 297.1 & 362.1 & 183.1 & - & 423 & 215.6 & - & 488.1 & 207.7 & - \\
\hline $\mathrm{F} / \mathrm{C}$ ratio & \multicolumn{4}{|c|}{$70 / 30$} & \multicolumn{3}{|c|}{$60 / 40$} & \multicolumn{3}{|c|}{$50 / 50$} \\
\hline Milk yield(g/day) & \multicolumn{4}{|c|}{$2.55 \pm 0.5$} & \multicolumn{3}{|c|}{$2.50 \pm 0.6$} & \multicolumn{3}{|c|}{$2.60 \pm 0.5$} \\
\hline Fat $(\%)$ & \multicolumn{4}{|c|}{$3.2 \pm 0.7$} & \multicolumn{3}{|c|}{$3.3 \pm 0.5$} & \multicolumn{3}{|c|}{$3.6 \pm 0.55$} \\
\hline Protein (\%) & \multicolumn{4}{|c|}{$3.2 \pm 0.3^{\mathrm{a}}$} & \multicolumn{3}{|c|}{$3.3 \pm 0.3^{\mathrm{a}}$} & \multicolumn{3}{|c|}{$3.7 \pm 0.4^{b}$} \\
\hline Lactose (\%) & \multicolumn{4}{|c|}{$4.4 \pm 0.3$} & \multicolumn{3}{|c|}{$4.4 \pm 0.3$} & \multicolumn{3}{|c|}{$4.6 \pm 0.15$} \\
\hline
\end{tabular}

${ }^{1} \mathrm{C}$ - concentrates; ${ }^{2} \mathrm{AH}$ - alfalfa hay; ${ }^{3} \mathrm{PGH}$ - polyphite grass hay; ${ }^{4} \mathrm{P}$ - pasture; ${ }^{5} \mathrm{RH}$ - ryegrass hay. ${ }^{\mathrm{a}, \mathrm{b}}=$ mean values for each group within a row with unlike superscript letters were significantly different $(p<0.05)$. 
The results obtained from fatty acid analysis are reported in Table 2, expressed as $\mathrm{g} / 100 \mathrm{~g}$ of total FA.

Table 2. Fatty acids (g/100g of total FA) of bulk goat milk samples. Data are expressed as mean \pm standard deviation.

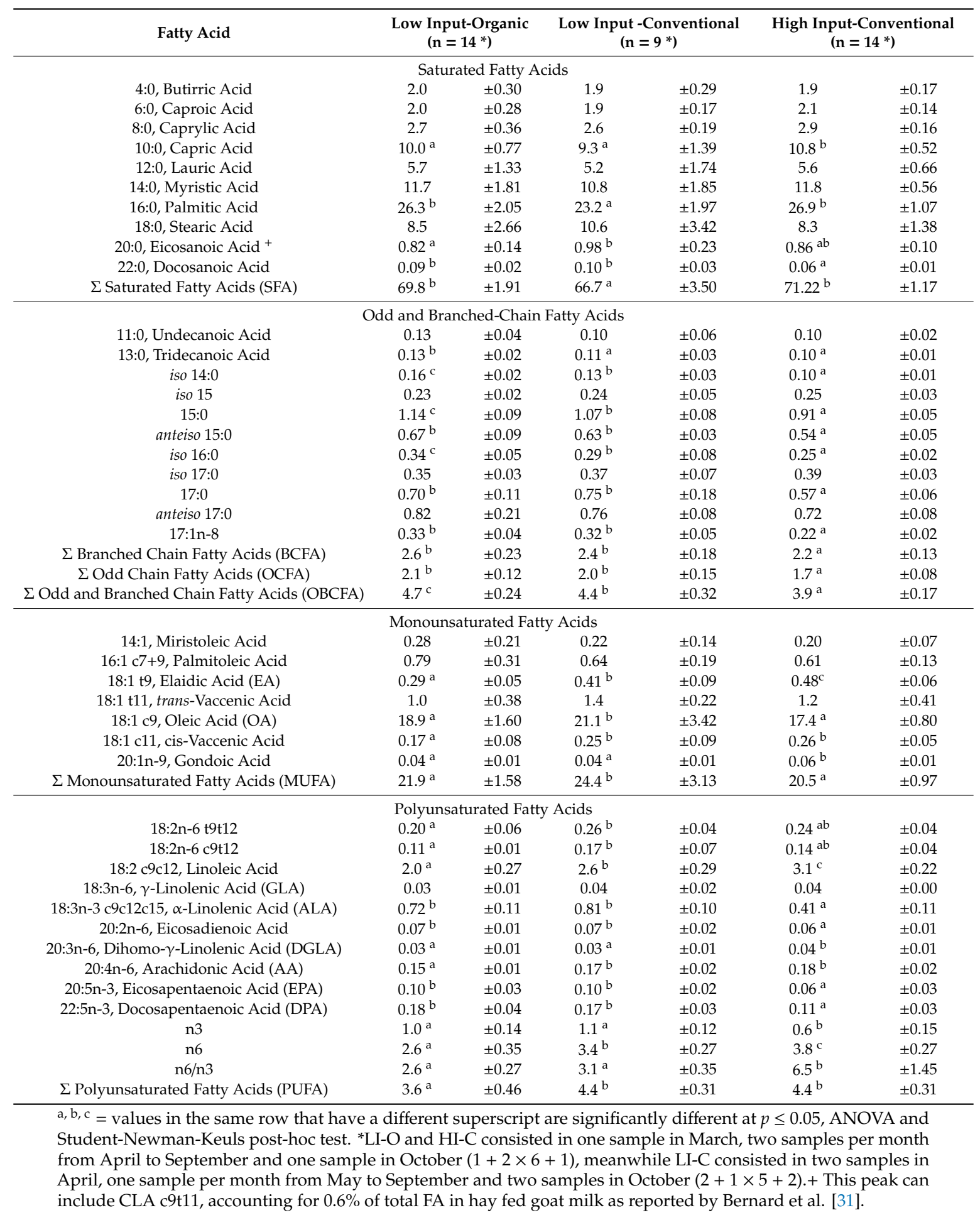

Detected fatty acids were divided into four groups according to their chemical structure. For each group, the sum $(\Sigma)$ was made. Particularly, for the OBCFA group we calculated the amount of branched-chain fatty acids ( $\Sigma$ BCFA), linear odd-chain fatty acids ( $\Sigma$ OCFA) and the total amount of 
both groups ( $\Sigma$ OBCFA). Oleic acid was found in higher concentrations in LI-systems samples $(21.1 \%$ in the conventional farm and $18.9 \%$ in the organic farm) than in the HI-system samples (17.4\%). Elaidic acid (EA) and linoleic acid (LA) were found to be higher $(p<0.05)$ in the HI farm milk $(0.48 \%$ and $3.1 \%$, respectively), followed by the LI-C farm milk ( $0.41 \%$ and $2.6 \%$, respectively) and, then, by the LI-O milk $(0.29 \%$ and $2.0 \%$, respectively). Alpha-linolenic acid (ALA) showed differences $(p<0.05)$ between the LI farms milk $(0.72 \%$ in the organic farm and $0.81 \%$ in the conventional farm) and the HI farm milk $(0.41 \%)$. PUFA of the $\mathrm{n} 3$ series were found in higher $(p<0.05)$ amounts in LI-O milk $(1 \%)$ and LI-C milk $(1.1 \%)$ than in HI-C milk $(0.6 \%)$. On the contrary, n6 PUFA were significantly higher $(p<0.05)$ in HI-C milk (3.8\%), followed by LI-C milk (3.4\%) and, then, by LI-O milk (2.6\%). Consequently, the n6/n3 ratio showed differences $(p<0.05)$ between LI groups, with values of 2.6 in the organic farm and 3.4 in the conventional farm, and the HI group, in which it reached a value of 3.8. Long chain n3 PUFA, EPA and DPA, resulted in higher values $(p<0.05)$ in the LI-systems than in the HI-system. DHA (22:6 n3) was detected only in trace and in a small number of samples. Significant differences $(p<0.05)$ were found among the three groups in the whole content of OBCFA, which ranged from $4.7 \%$ in the LI-O farm to $3.9 \%$ in the HI-C farm, and with the LI-C farm it reached an intermediate value of $4.4 \%$. Particularly, branched fatty acids iso14, iso16 and the linear-odd fatty acid 15:0 showed different $(p<0.05)$ amounts in LI-O, LI-C and HI-C samples. Branched-chain were the most representative, reaching values of $2.6 \%$, $2.4 \%$ and $2.2 \%$ in LI-O, LI-C and HI-C, respectively, while linear-odd chain fatty acids ranged from $2.1 \%$ in LI-O milk to $1.7 \%$ HI-C milk.

In Figure 1, the results obtained by principal component analysis (PCA) of data are reported.

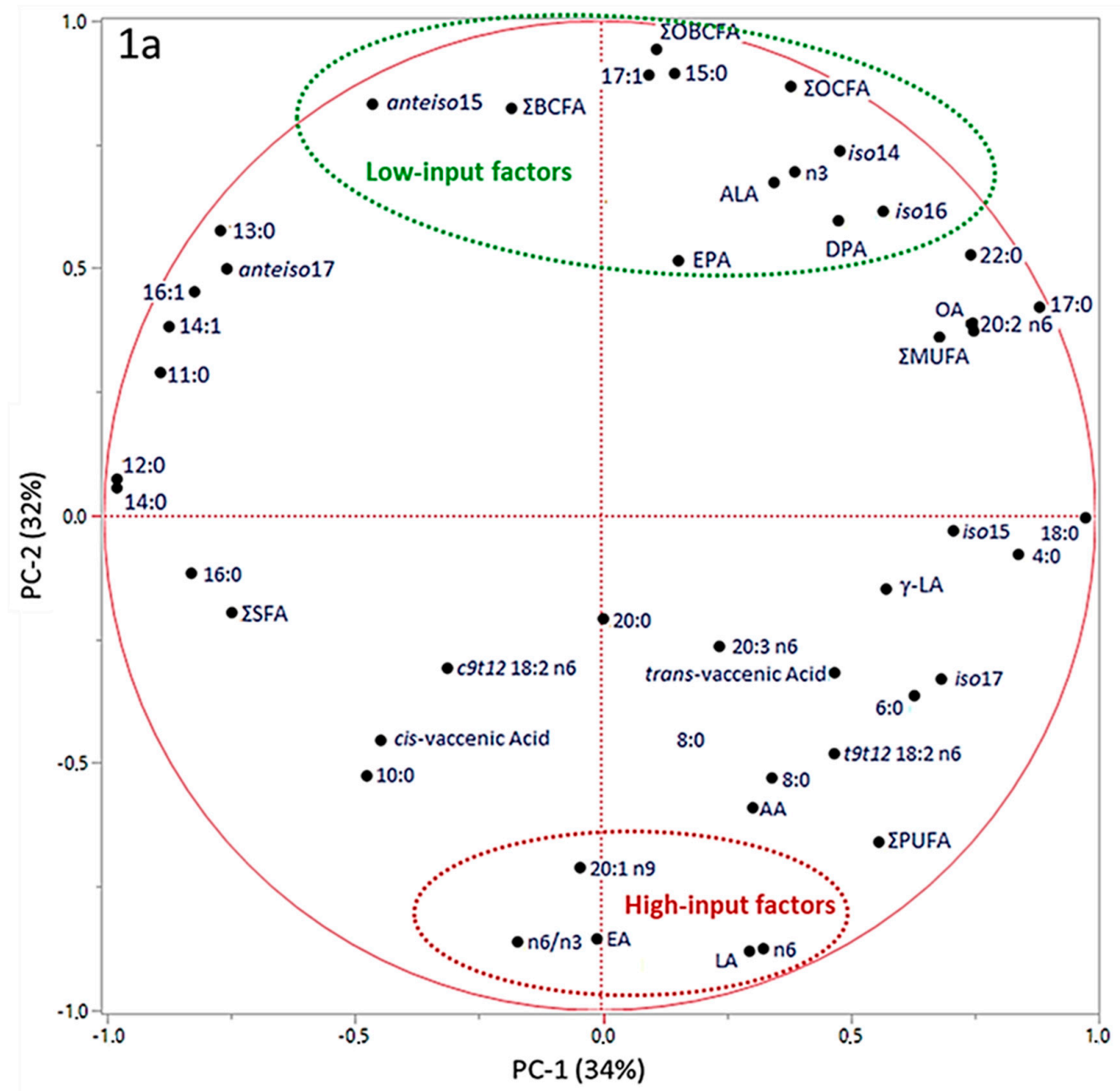

Figure 1. Cont. 


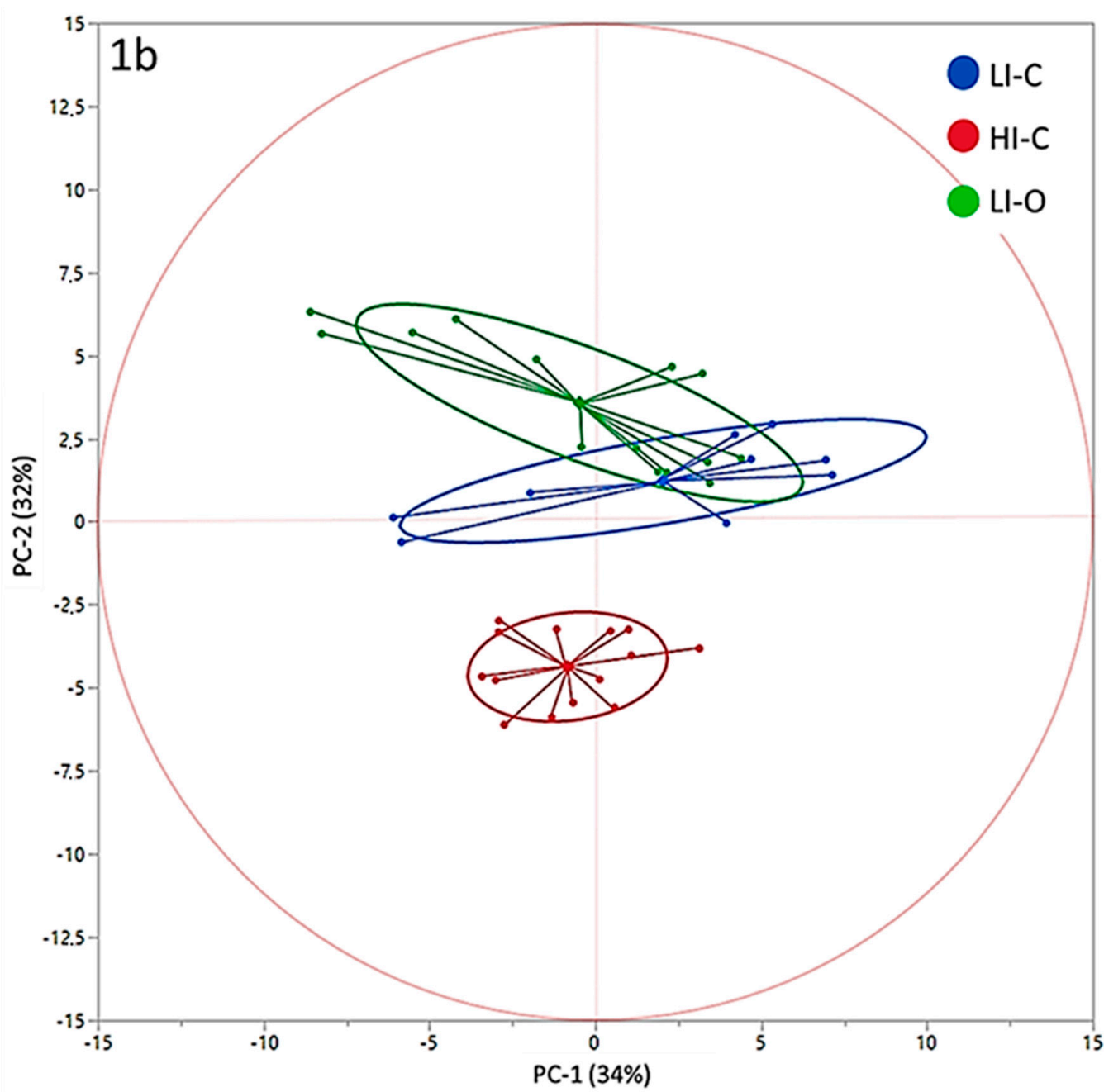

Figure 1. Principal Component Analysis Loadings Plot (a) and Scores Plot (b). a, b, c = values in the same row that have different superscript are significantly different at $p \leq 0.05$, ANOVA and Student-Newman-Keuls post-hoc test.

PC-1 and PC-2 have been chosen as coordinates on the $x$ - and $y$ - axes, accounting for $34 \%$ and $32 \%$ of total variance in data distribution, respectively. This combination of PCs has been chosen as it allowed for the best separation of the groups. In the correlation loadings plot (Figure 1a) we can see that OBCFA, EA, LA, ALA, n3 FA, n6 FA and n6/n3 ratio could be identified as factors that more significantly contributed to the variance among samples, by PC-2 vector's direction. The scores plot (Figure 1b) shows three clusters, with the average point, variability within the groups and density ellipses set at 0.68 (mean \pm 1 standard deviation) for each group. PC-2 allowed a discrimination among samples coming from the three different farms. Both LI-O and LI-C groups were distributed in the area of the two-dimensional space where the "low-input factors" (green) are positively correlated with PC-2, in line with the higher values found in these samples by chemical analyses. On the contrary, HI-C samples are more characterized by the "high-input factors", which presented negative loadings on PC-2. In Figure 2, the most influencing factors on clusters discrimination and their eigenvectors on the second component of PCA are reported. 


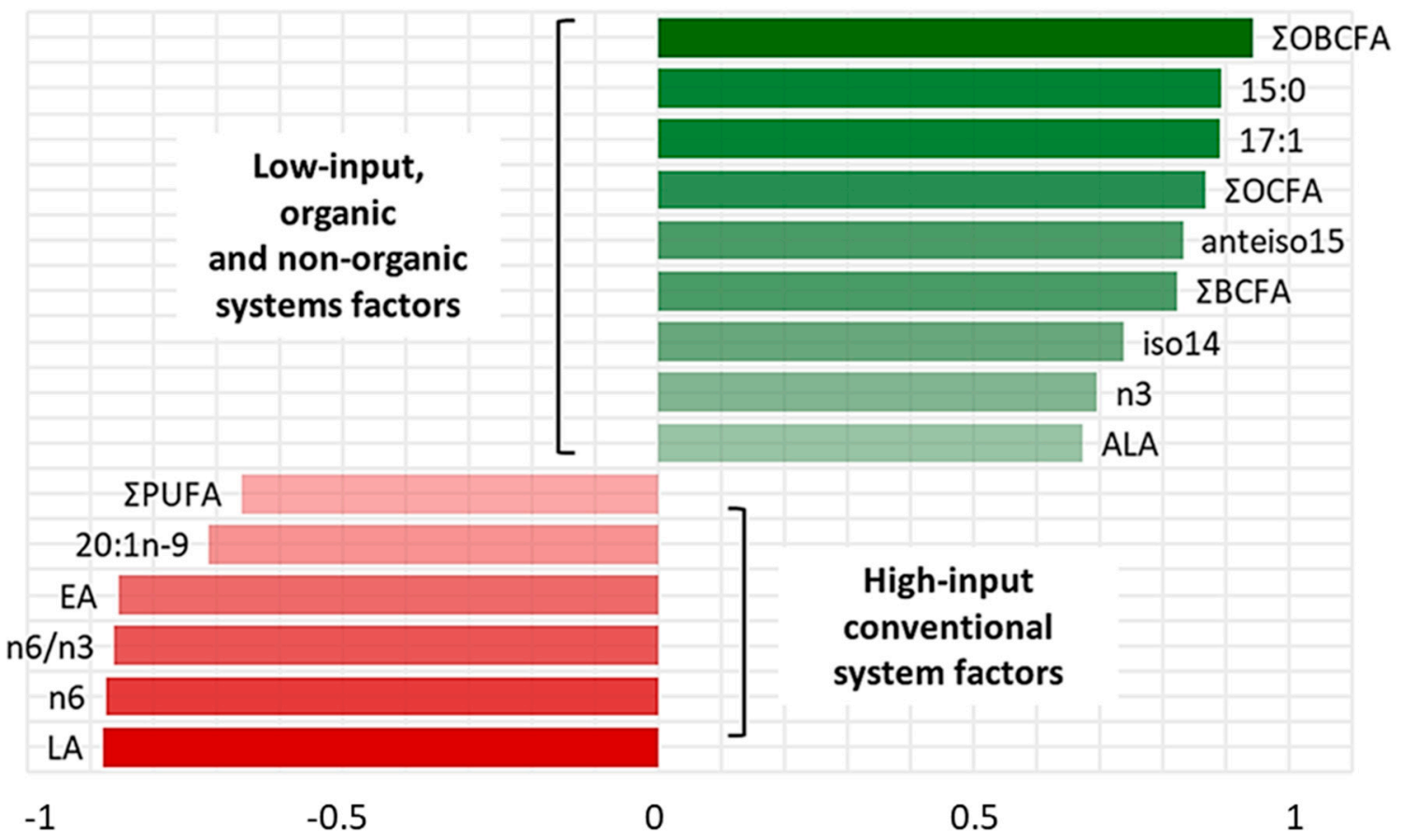

Figure 2. Principal Component-2 eigenvectors of factors considered as representative of the low-input and the high-input systems. Variables with absolute values of their eigenvectors equal or greater than 0.6 have been chosen. Factors with the higher absolute values of their eigenvectors are associated with a higher influence on data variability.

The factors taken into account could be divided in two groups, according to their positive or negative relation with PC-2. Variables selected in this model were total OBCFA, n3 and ALA, which showed the overall maximal values in LI-systems samples, while higher levels of LA, n6, EA, 20:1n9 and PUFA content were observed in the HI-system samples. In Table 3, results of the analysis of variance on PC-1 and PC-2 are reported. The ANOVA of the PC scores revealed that whereas PC-1 did not allow us to discriminate different samples, PC-2 effectively separated the three groups $(p<0.01)$ according to the livestock production system.

Table 3. ANOVA of the Principal Components (PCs) eigenvalues. Data are reported as mean \pm SEM.

\begin{tabular}{cccccccc}
\hline \multirow{2}{*}{$\begin{array}{c}\text { Principal } \\
\text { Component }\end{array}$} & \multicolumn{7}{c}{ Farm } \\
\cline { 2 - 8 } & \multicolumn{2}{c}{ Low Input-Organic } & Low Input-Conventional & \multicolumn{2}{c}{ High Input-Conventional } \\
\cline { 2 - 8 } & Mean & SEM & Mean & SEM & Mean & SEM & P \\
\hline PC-1 & -0.47 & 1.05 & 2.04 & 1.31 & -0.84 & 1.06 & 0.2123 \\
PC-2 & $3.57^{\mathrm{a}}$ & 0.40 & $1.23^{\mathrm{b}}$ & 0.50 & $-4.36^{\mathrm{c}}$ & 0.40 & $<0.0001$ \\
\hline
\end{tabular}

$\mathrm{a}, \mathrm{b}, \mathrm{c}=$ values in the same row that have different superscript are significantly different at $p \leq 0.05$, ANOVA and Student-Newman-Keuls post-hoc test.

\section{Discussion}

No significant differences were found in the proximate composition of milk samples coming from the different farms, except for the slight differences in protein amounts. In all three groups, fatty acids showed the characteristic fatty acid pattern of caprine milk and values of fatty acids from 6:0 to 10:0 agree with values previously reported in literature $[17,31,32]$. Fatty acids from 4 to 8 carbon atoms were not found to be significantly different in milk obtained from different farms and confirmed the previously observed results [17], proving that such differences in production systems did not modify volatile fatty acids proportion in goat milk. The proportion of oleic acid in milk is controlled by its plasma uptake and partly from desaturation of stearic acid by mammary $\Delta 9$-desaturase [33]. 
The desaturation ratio 18:1 c9/18:0 in the mammary gland is influenced by the diet, since the increase in availability of either PUFA or trans-FA inhibits the $\Delta 9$-desaturase. Consequently, the proportions of oleic acid in goat milk decrease with the increasing percentage of concentrate [17]. According to this, we detected the lowest values for oleic acid in samples of HI-C farm, in which goats were fed with the higher amount of concentrates $(50 \%$ of DMI). Even the concentration of trans18:1 isomers $(t 9+t 11)$ is related to the percentage of concentrate in the diet, and it increases when the concentrate proportion is higher [34]. Rumen microbial population is considered directly involved in this process, since trans18:1 isomers are intermediary products of ruminal biohydrogenation of the dietary PUFA [35]. The main factor that affects the biohydrogenation rate is the percentage of the concentrate in the diet [36]. In literature, vaccenic acid is the major component (about 36.2\%) of total trans 18:1 isomers [37]. In our study, vaccenic acid (18:1 t11) represented $70 \%$ to $80 \%$ of the detected trans $18: 1$ isomers, without differences among different farms. However, the lowest amount of VA was detected in LI-O milk and the highest in HI-C and LI-C milk. Elaidic acid (18:1 t9) relative content resulted different $(p<0.05)$ in the three groups of milk samples. The relative percentages of EA detected matched with the results obtained by Serment et al. [17], who reported an effect of the percentage of concentrate on the fatty acid profile in milk goats that produced a relative amount of $0.3 \%$ of EA in a lower concentrate diet versus an amount of $0.4 \%$ of EA in a higher concentrate one. These results are consistent with the knowledge that a decrease in the fiber content (or an increase of concentrate) in the goat daily ration would lead to a higher content of the trans18:1 fatty acids in milk (except 18:1 t11) [36,38].

In ruminants, the unsaturated fatty acids are metabolized by microorganisms in the rumen and undergo biohydrogenation and double-bond migration to yield a mixture of structural isomers (cis-trans isomers and positional isomers) [39]. PUFA quantities in ruminant milk generally increase with PUFA dietary intake, even if the transfer efficiency of PUFA from the diet to milk is low because of the biohydrogenation process that occurs in the rumen [33]. In our research, similar amounts of PUFA were detected, with a difference $(p<0.05)$ between samples coming from the high-input system $(4.41 \%)$ and samples coming from the low-input systems $(4.43 \%$ in the conventional one and $3.6 \%$ in the organic one). It is known that the fresh forage intake increases dietary PUFA supply [23,40-42]. However, some studies $[43,44]$ have reported that a high amount of concentrates in diet can cause a decrease in biohydrogenation processes, with a consequent increase of PUFA amounts. Moreover, in Table 3 it is shown that the higher amount of PUFA in HI-C milk is mainly due to the higher amount of n6FA in these samples. The concentration of linoleic acid, the most representative FA among PUFA, was higher in HI-system milk compared to LI-systems milk. These results agree with values reported in literature, specifically in the absence of lipids added to diets, as the proportion of LA on goat milk FAs is between $2 \%$ and $3 \%[15,17,32,36]$. Generally, all or most of LA in milk fat comes from dietary LA that escapes from rumen biohydrogenation activity, and its transfer to milk is related to the amount of this fatty acid that is ingested [45]. Most likely, we found higher LA values in HI-system milk because of the higher intake of concentrates by goats reared in this farm, according to the fact that by decreasing the $\mathrm{F} / \mathrm{C}$ ratio the LA concentration increases [36]. Alpha-linolenic acid and long chain $\mathrm{n}-3$ series in goat milk are influenced by a fresh grass-based diet that is a good source of ALA. Consequently, pasture induces an increase in ALA in ruminant milk [46]. In our results, ALA content was found to be significantly higher in LI-systems milk than in HI-system milk. The higher amount of ALA in LI-systems milk could be explained by the fact that goats at these farms had access to pastures normally enriched in ALA, and that were fed with a natural grassland hay, which had in the past showed a positive effect on ALA content in goat milk [36]. Furthermore, forage is rich in ALA, whereas cereals contain higher amounts of LA [45]. HI-C goats were fed with the highest amount of concentrates and the lowest F/C ratio. Similar amounts below or around the 1\% of ALA were reported by other authors in milk from Alpine goats fed a hay-based diet at a low percentage of concentrate and without lipid supplementation [17,31,47]. In the milk of Saanen goats fed with a high F/C ratio diet, Mele et al. [16] showed a presence of ALA (0.49\%) comparable to our results. In addition to total PUFA and ALA, CLA (LA-conjugated isomers) are generally considered as markers of fiber intake in ruminants [36]. 
CLA c9t11, which is the most representative of total CLAs, shows higher concentrations when the proportion of fresh grass intake increases [48]. Unfortunately, with our analytical equipment, provided with a $60 \mathrm{~m}$ TR-FAME TM column, we were able to separate two LA-non conjugated isomers, 18:2 t9t12 and 18:2 c9t12, but we had the coelution of the CLA c9t11 with 20:0. For this reason, the amount of 20:0 reported in Table 2 can include also CLA c9t11. EPA and DPA relative content in Alpine goat milk resulted in higher values than the ones reported by Bernard et al. [47]. The author studied fatty acids trend in Alpine goat milk, reporting values of $0.07 \%$ for EPA and $0.12 \%$ for DPA in milk goats fed with natural grassland hay. Differently, the relative amount of EPA we detected in HI-C milk (0.06\%) was lower than the amount reported by other authors [16] in Saanen milk $(0.11 \%)$. Since PUFA are not synthesized by tissues in ruminants, their concentration in milk is positively related to the dietary amount and to the decrease of rumen hydrogenation activity, such as a high forage/concentrate ratio. According to this, we found the highest amount of EPA and DPA in milk samples coming from the two LI-systems farms.

In our study, OBCFA showed differences $(p<0.05)$ between the HI-farm milk and the two LI-farms milk. In previous studies [4] linear odd-chain fatty acids were reported as the majority of ruminant milk OBCFA, followed by anteiso-fatty acids. In the present work we found the higher values in branched-chain fatty acids. The most representative were anteiso15:0 and anteiso17:0, which reached the higher values in LI-O milk in both cases $(0.7 \%$ and $0.8 \%$, respectively), then followed by iso-forms. These results follow the trend observed by Alonso et al. [32] who found that the most important OBCFA in quantitative terms in goat milk were the iso15:0 and anteiso15:0, iso17:0 and anteiso17:0 and iso16:0. We found the main differences in iso14:0, 15:0 and iso16:0 fatty acids, with the higher amount in LI-O milk, followed by LI-C milk and by HI-C milk. These differences may be relevant by a nutritional point of view. Indeed, 15:0 levels in subcutaneous adipose tissue and serum have been used as markers of intake of ruminant fat by humans [49-51]. Meanwhile, it is known that iso14:0 and iso16:0 levels in milk fat are related to the rumen functionality, showing a positive association with the presence of cellulolytic bacteria and decreasing when diets rich in starch are supplied to animals [5,52,53]. On the contrary, increasing the forage/concentrate $(\mathrm{F} / \mathrm{C})$ ratio in the diet resulted in a higher proportion of milk OBCFA, even if the effects of variation in the dietary $\mathrm{F} / \mathrm{C}$ ratio on OBCFA are not uniform over all studies found in literature [5]. In the present study, we found higher levels of total OBCFA in goats that had access to grazing and were fed with the higher amount of forages. These changes in milk OBCFA concentration might reflect the equilibrium in the rumen bacterial populations induced by the differences in dietary $\mathrm{F} / \mathrm{C}$ ratio and by the quality of the fiber supplied (fresh grass vs conserved forage).

Also, the n6/n3 ratio, considered as a healthy balance index, was evaluated. We obtained a difference $(p<0.05)$ between samples collected in the LI farms (both organic and conventional) and samples collected in the HI farm. The lower amounts of n6/n3 were detected in the LI-O milk, followed by LI-C milk and then by HI-C milk. A lower n6/n3 ratio is indicative of a forage-based diet [21] and this is consistent with the fact that in LI farms goats were fed with a higher amount of forage. Values obtained in this research for the LI-systems products display lower values for n6/n3 ratio than values reported in literature for goat milk (5.0) [54], suggesting a more favorable composition of products originated by these rearing systems.

According to our discussion regarding fatty acids composition in the different groups, variables associated with positive values of PC-2 eigenvectors (Figure 2, in green) could be considered as markers of the low-input systems, both organic and non-organic, mainly related to the higher $\mathrm{F} / \mathrm{C}$ ratio of the supplied diet and to the access to pastures. On the contrary, variables associated with negative values of PC-2 eigenvectors (Figure 2, in red) could be considered as markers of the high-input system, characterized by a lower $\mathrm{F} / \mathrm{C}$ ratio in the diet and by the exclusive use of conserved forages supplied in the barn. Thus, even if a partial overlapping between LI-O and LI-C is observable in the scores plot (Figure 1b), the analysis of variance of PC eigenvalues (Figure 2) revealed that the combination of original variables obtained with PCA on the first two components allowed us to identify three different clusters. It suggests that the total pattern of milk fatty acids is significantly influenced by the 
considered production systems, more so than single fatty acids. Moreover, LI-O and LI-C goats milk composition showed the largest variability of data (Figure $1 \mathrm{~b}$ ), putatively linked to seasonal variations and to the quantity and the quality of feed in pasture-based systems, compared with the HI-C milk farm, where the diet had very few variation all over the research time.

\section{Conclusions}

The present study have mainly demonstrated that goat milk from farms managed under a low-input rearing system showed differences if compared to milk from a high-input system farm. A multivariate statistical technique supported results found by analytical means. Differences were particularly detectable between the LI and the HI farming systems, but few differences were found between the two LI-system farms. The differences were mainly imputable to different amounts of some fatty acids, primarily OBCFA, n3FA, n6FA, ALA, LA and EA, selected by the Authors as factors related to the farming system.

Author Contributions: A.L. took up the investigation, the formal and data analysis and the writing of the paper. M.V. performed the main investigation and developed the methodology. V.M.M. co-supervised the research, validated the results and had an input on the writing-review and editing-of the paper. F.B. conceived and supervised the study and the writing-first draft and reviews.

Funding: This work was supported by the University of Milan [Piani di Sostegno alla Ricerca 2016-2017, Linea 2].

Acknowledgments: The authors acknowledge all the farmers for their availability in samples collection.

Conflicts of Interest: The authors declare no conflict of interest.

\section{References}

1. Bernard, L.; Bonnet, M.; Delavaud, C.; Delosière, M.; Ferlay, A.; Fougère, H.; Graulet, B. Milk fat globule in ruminant: major and minor compounds, nutritional regulation and differences among species. Eur. J. Lipid Sci. Technol. 2018, 120, 1700039. [CrossRef]

2. Hanuš, O.; Samkova, E.; Krizova, L.; Hasonova, L.; Kala, R. Role of fatty acids in milk fat and the influence of selected factors on their variability - a review. Molecules 2018, 23, 1636. [CrossRef]

3. Fievez, V.; Dohme, F.; Danneels, M.; Raes, K.; Demeyer, D. Fish oils as potent rumen methane inhibitors and associated effects on rumen fermentation in vitro and in vivo. Anim. Feed Sci. Technol. 2003, 104, 41-45. [CrossRef]

4. Fievez, V.; Colman, E.; Castro-Montoya, J.M.; Stefanov, I.; Vlaeminck, B. Milk odd- and branched-chain fatty acids as biomarkers of rumen function-An update. Anim. Feed Sci. Technol. 2002, 172, 51-65. [CrossRef]

5. Vlaeminck, B.; Fievez, V.; Cabrita, A.R.J.; Fonseca, A.J.M.; Dewhurst, R.J. Factors affecting odd- and branched-chain fatty acids in milk: A review. Anim. Feed Sci. Technol. 2006, 131, 389-417. [CrossRef]

6. Kaneda, T. Iso- and anteiso-fatty acids in bacteria: biosynthesis, function, and taxonomic significance. Microbiol. Rev. 1991, 55, 288-302. [PubMed]

7. Mackie, R.I.; White, B.A.; Bryant, M.P. Lipid metabolism in anaerobic ecosystems. Crit. Rev. Microbiol. 1991, 17, 449-479. [CrossRef] [PubMed]

8. Falchero, L.; Lombardi, G.; Gorlier, A.; Lonati, M.; Odoardi, M.; Cavallero, A. Variation in fatty acid composition of milk and cheese from cows grazed on two alpine pastures. Dairy Sci. Technol. 2010, 90, 657-672. [CrossRef]

9. Povolo, M.; Pelizzola, V.; Lombardi, G.; Tava, A.; Contarini, G. Hydrocarbon and fatty acid composition of cheese as affected by the pasture vegetation type. J. Agric. Food Chem. 2012, 60, 299-308. [CrossRef]

10. Yang, Z.; Liu, S.; Chen, X.; Chen, H.; Huang, M.; Zheng, J. Induction of apoptotic cell death and in vivo growth inhibition of human cancer cells by a saturated branched-chain fatty acid, 13-methyltetradecanoic acid. Cancer Res. 2000, 60, 505-509.

11. Ran-Ressler, R.R.; Khailova, L.; Arganbright, K.M.; Adkins-Rieck, C.K.; Jouni, Z.E.; Koren, O.; Ley, R.E.; Brenna, J.T.; Dvorak, B. Branched chain fatty acids reduce the incidence of necrotizing enterocolitis and alter gastrointestinal microbial ecology in a neonatal rat model. PLoS ONE 2011, 6, e29032. [CrossRef] [PubMed] 
12. Khaw, K.T.; Friesen, M.D.; Riboli, E.; Luben, R.; Wareham, N. Plasma phospholipid fatty acid concentration and incident coronary heart disease in men and women: the EPIC-Norfolk prospective study. PLoS Med. 2012, 9, e1001255. [CrossRef] [PubMed]

13. Forouhi, N.G.; Koulman, A.; Sharp, S.J.; Imamura, F.; Kröger, J.; Schulze, M.B.; Crowe, F.L.; Huerta, J.M.; Guevara, M.; Beulens, J.W.; et al. Differences in the prospective association between individual plasma phospholipid saturated fatty acids and incident type 2 diabetes: the EPIC-InterAct case-cohort study. Lancet Diabetes Endocrinol 2014, 2, 810-818. [CrossRef]

14. Ran-Ressler, R.R.; Bae, S.; Lawrence, P.; Wang, D.H.; Thomas Brenna, J. Branched-chain fatty acid content of foods and estimated intake in the USA. Br. J. Nutr. 2014, 112, 565-572. [CrossRef] [PubMed]

15. Martínez Marín, A.L.; Gómez-Cortés, P.; Gómez Castro, A.G.; Juárez, M.; Pérez Alba, L.M.; Pérez Hernández, M.; de la Fuente, M.A. Animal performance and milk fatty acid profile of dairy goats fed diets with different unsaturated plant oils. J. Dairy Sci. 2011, 94, 5359-5368. [CrossRef]

16. Mele, M.; Serra, A.; Buccioni, A.; Conte, G.; Pollicardo, A.; Secchiari, P. Effect of soybean oil supplementation on milk fatty acid composition from Saanen goats fed diets with different forage: concentrate ratios. Ital. J. Anim. Sci. 2008, 7, 297-311. [CrossRef]

17. Serment, A.; Schmidely, P.; Giger-Reverdin, S.; Chapoutot, P.; Sauvant, D. Effects of the percentage of concentrate on rumen fermentation, nutrient digestibility, plasma metabolites, and milk composition in mid-lactation goats. J. Dairy Sci. 2011, 94, 3960-3972. [CrossRef]

18. Chung, I.M.; Kim, J.K.; Lee, K.J.; Son, N.Y.; An, M.J.; Lee, J.H.; An, Y.J.; Kim, S.H. Discrimination of organic milk by stable isotope ratio, vitamin $\mathrm{E}$, and fatty acid profiling combined with multivariate analysis: A case study of monthly and seasonal variation in Korea for 2016-2017. Food Chem. 2018, 261, 112-123. [CrossRef]

19. Collomb, M.; Bisig, W.; Butikofer, U.; Sieber, R.; Bregy, M.; Etter, L. Fatty acid composition of mountain milk from Switzerland: comparison of organic and integrated farming system. Int. Dairy J. 2008, 18, 976-982. [CrossRef]

20. Malissiova, E.; Tzora, A.; Katsioulis, A.; Hatzinikou, M.; Tsakalof, A.; Arvanotoyannis, I.S.; Govaris, A.; Hadjichristodoulou, C. Relationship between production conditions and milk gross composition in ewe's and goat's organic and conventional farms in central Greece. Dairy Sci. Technol. 2015, 95, 437-450. [CrossRef]

21. Schwendel, B.H.; Wester, T.J.; Morel, P.C.H.; Tavendale, M.H.; Deadman, C.; Shadbolt, N.M.; Otter, D.E. Invited review: Organic and conventionally produced milk - an evaluation of factors influencing milk composition. J. Dairy Sci. 2015, 92, 721-746. [CrossRef] [PubMed]

22. Tsiplakou, E.; Kotrotsios, V.; Hadjigeorgiou, I.; Zervas, G. Differences in sheep and goats milk fatty acid profile between conventional and organic farming systems. J. Dairy Res. 2010, 77343-77349. [CrossRef] [PubMed]

23. Butler, G.; Nielsen, J.H.; Slots, T.; Seal, C.; Eyre, M.D.; Sanderson, R.; Leifert, C. Fatty acid and fat-soluble antioxidant concentrations in milk from high- and low-input conventional and organic systems: seasonal variations. J. Sci. Food Agric. 2008, 88, 1431-1441. [CrossRef]

24. Regulation (EU) 2018/484 of the European Parliament and of the Council of 30 May 2018 on organic production and labelling of organic products and repealing Council Regulation (EC) No 834/2007. OJ L 150, 14.6. 2018; $1-92$.

25. Pulina, G.; Avondo, M.; Molle, G.; Dias Francesconi, H.E.; Atzori, A.S.; Cannas, A. Invited review: Models for estimating feed intake in small ruminants. R. Bras. Zootec. 2013, 42, 675-690. [CrossRef]

26. Commission Regulation (EC) No 152/2009 of 27 January 2009 laying down the methods of sampling and analysis for the official control of feed. OJ L 54, 26.2. 2009; 1-130.

27. ISO 9622 | IDF 141:2013: Milk and liquid milk products — Guidelines for the application of mid-infrared spectrometry. ISO and IDF 2013.

28. Folch, J.; Lees, M.; Sloane Stanley, G.H. A simple method for the isolation and purification of total lipids from animal tissues. J. Biol. Chem. 1957, 226, 497-509. [PubMed]

29. Christie, W.W. Preparation of derivatives of fatty acids. In Lipid Analysis. Isolation, Separation, Identification and Structural Analysis of Lipids, Third Edition; Christie, W.W., Ed.; The Oily Press: Bridgwater, UK, 2003; pp. 205-215. ISBN 0-9531949-5-7.

30. Ulberth, F.; Gabernig, R.G.; Schrammel, F. Flame-ionization detector response to methyl, ethyl, propyl, and butyl esters of fatty acids. J. Am. Oil Chem. Soc. 1999, 76, 263-266. [CrossRef] 
31. Bernard, L.; Rouel, J.; Leroux, C.; Ferlay, A.; Faulconnier, Y.; Legrand, P.; Chilliard, Y. Mammary lipid metabolism and milk fatty acid secretion in alpine goats fed vegetable lipids. J. Dairy Sci. 2005, 88, 1478-1489. [CrossRef]

32. Alonso, L.; Fontecha, J.; Lozada, L.; Fraga, M.J.; Juàrez, M. Fatty acid composition of caprine milk: major, branched chain, and trans fatty acids. J. Dairy Sci. 1999, 82, 878-884. [CrossRef]

33. Chilliard, Y.; Ferlay, A.; Doreau, M. Effect of different types of forages, animal fat or marine oils in cow's diet on milk fat secretion and composition, especially conjugated linoleic acid (CLA) and polyunsaturated fatty acids. Livest. Prod. Sci. 2001, 70, 31-48. [CrossRef]

34. Chilliard, Y.; Ferlay, A.; Rouel, J.; Lamberet, G. A review of nutritional and physiological factors affecting goat milk lipid synthesis and lipolysis. J. Dairy Sci. 2003, 86, 1751-1770. [CrossRef]

35. Glasser, F.; Ferlay, A.; Chilliard, Y. Oilseed Lipid Supplements and Fatty Acid Composition of Cow Milk: A Meta-Analysis. J. Dairy Sci. 2008, 91, 4687-4703. [CrossRef] [PubMed]

36. Chilliard, Y.; Glasser, F.; Ferlay, A.; Bernard, L.; Rouel, J.; Doreau, M. Diet, rumen biohydrogenation and nutritional quality of cow and goat milk fat. Eur. J. Lipid Sci. Technol. 2007, 109, 828-855. [CrossRef]

37. LeDoux, M.; Rouzeau, A.; Bas, P.; Sauvant, D. Occurrence of trans-C18:1 fatty acid isomers in goat milk: effect of two dietary regimens. J. Dairy Sci. 2002, 85, 190-197. [CrossRef]

38. Hanlein, G.F.W. Goat milk in human nutrition. Small Rumin. Res. 2004, 51, 155-163. [CrossRef]

39. Bickerstaffe, R.; Noakes, D.E.; Annison, E.F. Quantitative aspects of fatty acid biohydrogenation, absorption and transfer into milk fat in the lactating goat, with special reference to the cis- and trans-isomers of octadecenoate and linoleate. Biochem. J. 1972, 130, 607-617. [CrossRef] [PubMed]

40. D’Urso, M.; Cutrignelli, I.; Calabrò, S.; Bovera, F.; Tudisco, R.; Piccolo, V.; Infascelli, F. Influence of pasture on fatty acid profile of goat milk. J. Anim. Physiol. Anim. Nutr. 2008, 92, 405-410. [CrossRef]

41. Butler, G.; Stergiadis, S.; Seal, C.; Eyre, M.; Leifert, C. Fat composition of organic and conventional retail milk in northeast England. J. Dairy Sci. 2011, 94, 24-36. [CrossRef]

42. Elgersma, A.; Tammingab, S.; Ellenca, G. Modifying milk composition through forage. Anim. Feed Sci. Technol. 2006, 131, 207-225. [CrossRef]

43. Loor, J.; Ueda, K.; Ferlay, A.; Chilliard, Y.; Doreau, M.J. Biohydrogenation, Duodenal Flow, and Intestinal Digestibility of Trans Fatty Acids and Conjugated Linoleic Acids in Response to Dietary Forage:Concentrate Ratio and Linseed Oil in Dairy Cows. J. Dairy Sci. 2004, 87, 2472-2485. [CrossRef]

44. Kalsehur, K.F.; Teter, B.B.; Piperova, L.S.; Erdman, R.A. Effect of Dietary Forage Concentration and Buffer Additionon Duodenal Flow of Trans-C18:1 Fatty Acids and Milk Fat Production in Dairy Cows. J. Dairy Sci. 1997, 80, 2104-2114. [CrossRef]

45. Khiaosa-ard, R.; Klevenhusen, F.; Soliva, C.R.; Kreuzer, M.; Leiber, F. Transfer of linoleic and linolenic acid from feed to milk in cows fed isoenergetic diets differing in proportion and origin of concentrates and roughages. J. Dairy Res. 2010, 77, 331-336. [CrossRef] [PubMed]

46. Chilliard, Y.; Ferlay, A. Dietary lipids and forages interactions on cow and goat milk fatty acid composition and sensory properties. Reprod Nutr. Dev. 2004, 44, 467-492. [CrossRef] [PubMed]

47. Bernard, L.; Shingfield, K.J.; Rouel, J.; Ferlay, A.; Chilliard, Y. Effect of plant oils in the diet on performance and milk fatty acid composition in goats fed diets based on grass hay or maize silage. Br. J. Nutr. 2009, 101, 213-224. [CrossRef] [PubMed]

48. Ricordeau, G. Etat des recherches sur le lait de chèvre en France. Lait 1993, 73, 443-453. [CrossRef]

49. Wolk, A.; Vessby, B.; Ljung, H.; Barrefors, P. Evaluation of a biological marker of dairy fat intake. Am. J. Clin. Nutr. 1998, 68, 291-295. [CrossRef] [PubMed]

50. Smedman, A.E.; Gustafsson, I.B.; Berglund, L.G.; Vessby, B.O. Pentadecanoic acid in serum as a marker for intake of milk fat: relations between intake of milk fat and metabolic risk factors. Am. J. Clin. Nutr. 1999, 69, 22-29. [CrossRef] [PubMed]

51. Warensjo, E.; Jansson, J.H.; Bergkund, L.; Boman, K.; Ahrén, B.; Weinehall, L.; Lindahl, B.; Hallmans, G.; Vessby, B. Estimated intake of milk fat is negatively associated with cardiovascular risk factors and does not increase the risk of a first acute myocardial infarction. A prospective case-control study. Br. J. Nutr. 2004, 91, 635-642. [CrossRef] [PubMed]

52. Nielsen, T.S.; Sejrsen, K.; Andersen, H.R.; Lund, P.; Straarup, E.M. Effect of silage type and energy concentration on conjugated linoleic acid (CLA) in milk fat from dairy cows. J. Anim. Feed Sci. 2004, 13, 697-700. [CrossRef] 
53. Shingfield, K.J.; Salo-Vaananen, P.; Pahkala, E.; Toivonen, V.; Jaakkola, S.; Piironen, V.; Huhtanen, P. Effect of forage conservation method, concentrate level and propylene glycol on the fatty acid composition and vitamin content of cows' milk. J. Dairy Res. 2005, 72, 1-13. [CrossRef]

54. Markiewicz-Kęszycka, M.; Czyżak-Runowska, G.; Lipińska, P.; Wójtowski, A. Fatty acid profile of milk - A review. Bull. Vet. Inst. Pulawy 2013, 57, 135-139. [CrossRef]

(C) 2019 by the authors. Licensee MDPI, Basel, Switzerland. This article is an open access article distributed under the terms and conditions of the Creative Commons Attribution (CC BY) license (http://creativecommons.org/licenses/by/4.0/). 